\title{
In vitro cytotoxicity assessment of ferulic, caffeic and $p$-coumaric acids on human renal cancer cells
}

\author{
Avaliação da citotoxicidade in vitro dos ácidos ferúlico, cafeico e p-cumárico em células renais \\ tumorais humanas
}

\begin{abstract}
Rita Caparica ${ }^{1,2}$, Ana Júlio ${ }^{1,2}$, André Rolim Baby ${ }^{3}$, Tânia Santos de Almeida ${ }^{1,4, \#}$, and João Guilherme Costa ${ }^{1, \#}$
${ }^{1}$ CBIOS-Universidade Lusófona's Research Center for Biosciences \& Health Technologies, Campo Grande 376, 1749-024

Lisbon, Portugal; ${ }^{2}$ Department of Biomedical Sciences, University of Alcalá, Ctra. Madrid-Barcelona Km. 33.600, Alcalá de Henares, 28871 Madrid, Spain; ${ }^{3}$ Department of Pharmacy, School of Pharmaceutical Sciences, University of São Paulo, 580 Prof. Lineu Prestes Av., Bl. 15, São Paulo, SP 05508-900, Brazil; ${ }^{4} \mathrm{CQB}, \mathrm{CQE}$ and Department of Chemistry and Biochemistry, Faculty of Sciences, University of Lisbon, Campo Grande 1749-016 Lisbon, Portugal

\# Shared senior authorship
\end{abstract}

Corresponding authors: tania.almeida@ulusofona.pt; jgcosta@ulusofona.pt

\begin{abstract}
Bioactive compounds from natural sources have been extensively studied as potential therapeutic agents, due to their chemical, structural, and biological properties. Among them, hydroxycinnamic acids emerge with a very interesting pharmacological potential to prevent and treat several diseases, including cancer. However, while some studies support their anticancer activity, other reports indicate otherwise. Since the impact of these compounds on renal cancer is not well established, further studies are needed to better understand their biological effects and their potential therapeutic uses in this cancer.

In this work, the cytotoxicity of three hydroxycinnamic acids: ferulic, caffeic and $p$-coumaric acids, was evaluated on 786-O human renal cancer cells by MTT and CV assays. At concentrations up to $250 \mu \mathrm{M}$, none of the studied natural compounds showed cytotoxic effects to $786-\mathrm{O}$ cell line. At higher concentrations (500 and $1000 \mu \mathrm{M})$, while ferulic acid also did not significantly influence the cell viability of 786-O cells, $p$-coumaric and caffeic acids decreased the renal cancer cells viability. Nevertheless, further studies on the biological activity of these compounds, using other methodologies, as well as using other cancer cell models, should be performed.
\end{abstract}

Keywords: Ferulic acid, caffeic acid, $p$-coumaric acid, cytotoxicity, 786-O cells

\section{Resumo}

Os compostos bioativos provenientes de produtos naturais têm sido amplamente estudados como potenciais agentes terapêuticos, devido às suas propriedades químicas, estruturais, e biológicas. De entre estes, os ácidos hidroxicinâmicos emergem com um potencial farmacológico muito interessante para prevenir e tratar várias doenças, incluindo o cancro. No entanto, enquanto alguns estudos demonstram a sua atividade antitumoral, outros estudos indicam o oposto. Uma vez que o impacto desses compostos no cancro renal não está bem estabelecido, são necessários mais estudos para compreender melhor os seus efeitos biológicos e os seus potenciais usos terapêuticos neste cancro.

Neste trabalho, a citotoxicidade de três ácidos hidroxicinâmicos: ácidos ferúlico, cafeico e $p$-cumárico foi avaliada em células tumorais renais humanas 786-O, através dos ensaios do MTT e do CV. Nenhum dos compostos naturais estudados, até $250 \mu \mathrm{M}$, mostrou efeitos citotóxicos na linha celular 786-O. A concentrações acima de $250 \mu \mathrm{M}$, enquanto que o ácido ferúlico não influenciou significativamente a viabilidade celular das células 786-O, os ácidos $p$-cumárico e cafeico diminuiram a viabilidade das células renais tumorais. No entanto, novos estudos sobre a atividade biológica destes compostos, utilizando outras metodologias, bem como outros modelos celulares tumorais, devem ser realizados.

Palavras-chave: Ácido ferúlico, ácido cafeico, ácido $p$-cumárico, citotoxicidade, células 786-O 


\section{Introduction}

Natural resources, such as plants, remain one of the most significant origins of active compounds for therapeutic applicability due to their unique properties, such as their chemical and structural diversity $(1,2)$. Among them, phenolic compounds are likely the most explored natural compounds due to their potential health benefits (3-5).

Phenolic compounds, naturally produced by plants, are very well-known bioactive compounds. In the plant kingdom, phenolics represent the second most abundant group of organic compounds and are derived from shikimate, pentose phosphate, and phenylpropanoid pathways (6). Their structure consists of an aromatic ring containing at least one hydroxyl group $(6,7)$. Due to their chemical, structural, and known biological properties, phenolic compounds have been extensively studied as potential therapeutic agents. $(3,8,9)$. Several studies describe the beneficial effects of these natural compounds, including their antitumor and antioxidant activities (6,10-15).

Phenolic compounds can be classified into two main groups: flavonoids and non-flavonoids. Phenolic acids, flavonoids, and tannins represent some of their subclasses, which are the most important in the human diet $(6,7,16)$. Among them, phenolic acids are amongst the bioactive compounds most commonly found in plants. Phenolic acids are divided into two main groups, the hydroxycinnamic acids (eg. cinnamic, ferulic, sinapic acids) and the hydroxybenzoic acids (e.g., gallic, vanilic and p-hydroxybenzoic acids) comprised by nine- and seven-carbon structure, respectively $(2,4,8,17)$.

The hydroxycinnamic acids are the largest group of phenolic acids, and some studies have shown their benefits to human health, particularly in preventing diseases that may be caused by oxidative stress, such as cancer or inflammatory and cardiovascular diseases $(2,18)$. Thus, in this context, and to explore the biological potential of these compounds, three hydroxycinnamic acids: ferulic, caffeic, and $p$-coumaric acids (Figure 1) were selected for this study.

Ferulic acid (4-hydroxy-3-methoxycinnamic acid), caffeic acid (3,4-dihydroxycinnamic acid) and $p$-coumaric acid (3-(4-hydroxyphenyl)-2-propenoic acid) are commonly present in dietary sources, such as plants (e.g., bamboo shoots, eggplant, ginseng), cereals (e.g., corn, rice, wheat), vegetables (e.g., radish, beans, red beet), beverages (e.g., coffee, wine), and fruits (e.g., orange, grapefruit, apples) $(2,17,19-22)$. The amount of these hydroxycinnamic acids present in the previously mentioned sources varies greatly. For example, the presence

\section{Introdução}

Os recursos naturais, como as plantas, continuam a ser uma das fontes mais relevantes de compostos ativos com aplicabilidade terapêutica, devido às suas propriedades únicas, como a sua diversidade química e estrutural $(1,2)$. Entre eles, os compostos fenólicos são provavelmente os compostos naturais mais explorados, devido aos seus potenciais benefícios para a saúde (35).

Os compostos fenólicos, produzidos naturalmente pelas plantas, são compostos bioativos bem conhecidos. No reino vegetal, estes compostos são o segundo grupo mais abundante de compostos orgânicos e derivam das vias xikimato, pentose-fosfato e fenilpropanóide (6). A sua estrutura consiste num anel aromático contendo pelo menos um grupo hidroxilo $(6,7)$. Devido às suas propriedades químicas, estruturais e biológicas conhecidas, os compostos fenólicos têm sido extensivamente estudados como potenciais agentes terapêuticos $(3,8,9)$. Vários estudos descrevem os efeitos benéficos desses compostos naturais, incluindo as suas atividades antitumorais e antioxidantes $(6,10-15)$.

Os compostos fenólicos podem ser classificados em dois grupos principais: flavonóides e não flavonóides. Os ácidos fenólicos, flavonóides e taninos representam algumas das suas subclasses, as quais são as mais importantes na dieta humana $(6,7,16)$. Entre eles, os ácidos fenólicos estão entre os compostos bioativos que são mais comuns encontrar em plantas. Os ácidos fenólicos são divididos em dois grupos principais, os ácidos hidroxicinâmicos (ex. ácidos cinâmico, ferúlico, sinápico) e os ácidos hidroxibenzóicos (ex. ácidos gálico, vanílico e p-hidroxibenzóico), constituídos por uma estrutura de nove e sete carbonos, respetivamente $(2,4,8,17)$.

Os ácidos hidroxicinâmicos são o maior grupo de ácidos fenólicos e alguns estudos têm demonstrado os seus benefícios na saúde humana, particularmente na prevenção de doenças que podem ser causadas pelo stresse oxidativo, como cancro ou doenças inflamatórias e cardiovasculares $(2,18)$.

Assim, neste contexto e para explorar o potencial biológico destes compostos, três ácidos hidroxicinâmicos: os ácidos ferúlico, cafeico e $p$-cumárico (Figura 1) foram selecionados para serem estudados.

O ácido ferúlico (ácido 4-hidroxi-3-metoxicinâmico), o ácido cafeico (ácido 3,4-di-hidroxicinâmico) e o ácido p-cumárico (ácido 3-(4-hidroxifenil)-2-propenóico) encontram-se habitualmente presentes na dieta alimentar, como em plantas (ex. rebentos de bambu, beringela, ginseng), cereais (ex. milho, arroz, trigo), legumes (ex. 
A

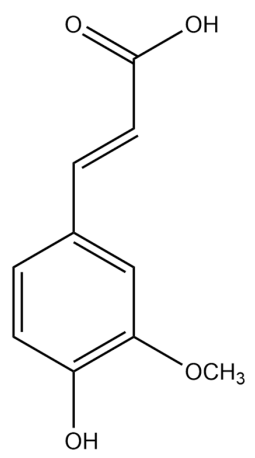

Ferulic acid/ Ácido ferúlico

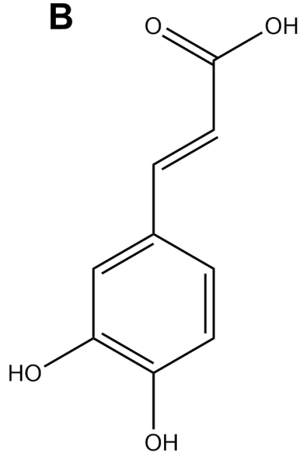

Caffeic acid/ Ácido cafeico

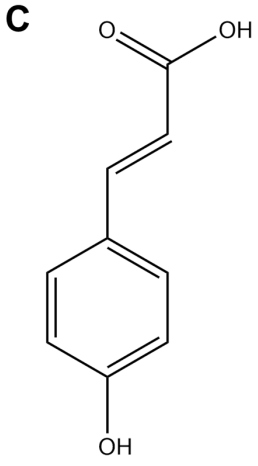

p-coumaric acidl

Figure 1 - Chemical structure of the ferulic acid (A), caffeic acid (B) and $p$-coumaric acid (C) Figura 1 - Estrutura química do ácido ferúlico (A), ácido cafeico (B) e ácido $p$-cumárico (C)

of $p$-coumaric acid may range from $0.5 \mathrm{mg} / \mathrm{kg}$ dry matter (DM) in blackberries to $3700 \mathrm{mg} / \mathrm{kg}$ DM in mushrooms (21).

The synthesis of these hydroxycinnamic acids in plants occurs through the shikimate pathway, starting with L-phenylalanine and/or L-tyrosine as precursors. Briefly, phenylalanine and tyrosine are converted into $p$-coumaric acid that is then hydroxylated to form caffeic acid that forms ferulic acid by methylation $(2,6,20)$.

Considering the biological activity of these phenolic acids, many studies have shown the wide range of biologic effects of ferulic, caffeic, and $p$-coumaric acids $(2,5,15,17,19-22)$. Nonetheless, there are some controversial reports concerning the anticancer potential of the studied phenolic acids. Therefore, it is essential to conduct more studies in various cell models to attempt to clarify the biological activity and the potential therapeutic use of these bioactive compounds. The carcinogenic potential of these compounds should also be considered, as there are some studies reporting this effect for caffeic acid (17).

Renal cell carcinoma (RCC) is the most common type of kidney cancer, representing up to $5 \%$ of all adult malignancies. Furthermore, since this type of kidney cancer is highly vascularized, metastatic, and has a low response to adjuvant therapies and surgery, it is relevant to find new and more effective treatments (23-27). Bearing all of this in mind, the aim of this work was to perform an overall review of the impact of ferulic, caffeic, and $p$-coumaric acids on different tumor cell lines and to experimentally study the impact rabanete, feijão, beterraba vermelha), bebidas (ex. café, vinho) e frutas (ex. laranja, toranja, maçã) $(2,17,19-22)$. A quantidade destes ácidos hidroxicinâmicos presentes nas fontes mencionadas anteriormente varia muito. Por exemplo, a presença de ácido $p$-cumárico pode variar de $0,5 \mathrm{mg} / \mathrm{kg}$ de matéria seca (MS) em amoras a 3700 $\mathrm{mg} / \mathrm{kg}$ MS em cogumelos (21).

A síntese desses ácidos hidroxicinâmicos nas plantas ocorre através da via do xikimato, começando com Lfenilalanina e/ou L-tirosina como precursores. Resumidamente, a fenilalanina e a tirosina são convertidas em ácido $p$-cumárico, que é posteriormente hidroxilado para formar o ácido cafeico que por sua vez origina o ácido ferúlico por metilação $(2,6,20)$.

Considerando a atividade biológica desses ácidos fenólicos, muitos estudos têm demonstrado a ampla gama de efeitos biológicos dos ácidos ferúlico, cafeico e $p$-cumárico $(2,5,15,17,19-22)$. No entanto, no que se refere ao potencial antitumoral dos ácidos fenólicos estudados, existem alguns resultados controversos. Portanto, é essencial realizar mais estudos em vários modelos celulares, com o intuito de esclarecer a atividade biológica e o potencial uso terapêutico destes compostos bioativos. O potencial carcinogénico destes compostos também deve ser considerado, uma vez que existem alguns estudos que reportam este efeito para o ácido cafeico (17).

O carcinoma de células renais (CCR) é o tipo mais comum de cancro renal, representando até $5 \%$ de todas as doenças malignas em adultos. Para além disto, como este tipo de cancro renal é altamente vascularizado, metastático e apresenta uma baixa resposta às terapêuticas adjuvantes e à cirurgia, é relevante encontrar tratamentos novos e mais eficazes (23-27). Tendo tudo isto em consideração, o objetivo deste trabalho foi realizar 
of these compounds on the well-established 786-O in vitro human renal cancer cell model. To the best of our knowledge, there are no previous in vitro studies that evaluate the effect of these compounds on human renal cancer.

\section{Materials and Methods}

\section{Materials}

The following reagents and solvents were purchased from Sigma-Aldrich (Saint Louis, MO, USA), phosphate buffered saline (PBS; $0.01 \mathrm{M}, \mathrm{pH}$ 7.4), trypsin, penicillin-streptomycin (pen/strep) solution, dimethyl sulfoxide (DMSO), ethanol, acetic acid, hydrogen peroxide $\left(\mathrm{H}_{2} \mathrm{O}_{2}\right)$, thiazolyl blue tetrazolium bromide (MTT), crystal violet (CV), $p$-coumaric acid, and caffeic acid. Fetal bovine serum (FBS) and Dulbecco's Modified Eagle's Medium (DMEM) were purchased from Biowest (Nuaillé, France). Ferulic acid was obtained from Henrifarma (São Paulo, Brazil).

Ferulic acid, $p$-coumaric acid, and caffeic acid solutions were prepared in DMSO. The final concentration of DMSO was $0.5 \%(\mathrm{v} / \mathrm{v})$ for all experiments.

\section{Cell Culture}

The 786-O human adenocarcinoma cells were obtained from the American Type Culture Collection (ATCC; Manassas, VA, USA). Cells were cultured in high glucose DMEM medium supplemented with $10 \%$ FBS and $1 \%$ pen/strep, at $37^{\circ} \mathrm{C}$ in a humidified atmosphere containing $5 \% \mathrm{CO}_{2}$.

\section{MTT assay}

Cell viability was determined using the MTT reduction assay. 786-O cells were seeded at a density of $3 \times 10^{3}$ per well in 96-well plates and incubated for $24 \mathrm{~h}$. Afterward, cells were treated with ferulic acid, $p$-coumaric acid or caffeic acid $(0-250 \mu \mathrm{M})$ for $48 \mathrm{~h}$. A solution of $\mathrm{H}_{2} \mathrm{O}_{2}(1 \mathrm{mM})$ was used as a positive control, while $0.5 \%(\mathrm{v} / \mathrm{v})$ of DMSO was used as vehicle control. The MTT reduction assay was then performed according to previously published procedures $(28,29)$. Absorbance values for the vehicle-treated control cells correspond to $100 \%$ of cell viability. For this assay, at least two independent experiments were carried out and at least six replicates were used for each condition in each independent experiment. uma revisão geral do impacto dos ácidos ferúlico, cafeico e $p$-cumárico em diferentes linhas celulares tumorais e estudar experimentalmente o impacto destes compostos nas células 786-O, um modelo in vitro de cancro renal humano bem estabelecido. Adicionalmente, tanto quanto sabemos não existem estudos prévios in vitro que avaliem o efeito destes compostos em cancro renal humano.

\section{Materiais e Métodos}

\section{Materiais}

Os reagentes e solventes utilizados adquiridos à SigmaAldrich (Saint Louis, MO, EUA) foram o tampão fosfato $(0,01 \mathrm{M}, \mathrm{pH} 7,4)$, a tripsina, a solução de penicilinaestreptomicina, o dimetilsulfóxido (DMSO), o etanol, o ácido acético, o peróxido de hidrogénio $\left(\mathrm{H}_{2} \mathrm{O}_{2}\right)$, o brometo de tetrazólio azul de tiazolil (MTT), o cristal violeta $(\mathrm{CV})$, o ácido $p$-cumárico e o ácido cafeico. $\mathrm{O}$ soro bovino fetal (FBS) e o meio de cultura Dulbecco's Modified Eagle's Medium (DMEM) foram adquiridos à Biowest (Nuaillé, França). O ácido ferúlico foi obtido pela Henrifarma (São Paulo, Brasil).

Os ácidos ferúlico, cafeico e $p$-cumárico foram preparados em DMSO. A concentração final de DMSO foi de $0.5 \%(\mathrm{v} / \mathrm{v})$ em todas as experiências realizadas.

\section{Cultura celular}

As células de adenocarcinoma humano 786-O foram adquiridas à American Type Culture Collection (ATCC; Manassas, VA, EUA). As células foram cultivadas em meio DMEM com elevada concentração de glucose suplementado com $10 \%$ de FBS e $1 \%$ de solução de penicilina-estreptomicina e mantidas a $37{ }^{\circ} \mathrm{C}$ sob uma atmosfera húmida contendo $5 \%$ de $\mathrm{CO}_{2}$.

\section{Ensaio de redução de MTT}

A viabilidade celular foi determinada utilizando o ensaio de redução do MTT. Para tal, as células 786-O foram cultivadas a uma densidade de $3 \times 10^{3}$ por poço, em placas de 96 poços e incubadas durante $24 \mathrm{~h}$. Em seguida, as células foram tratadas com os ácidos ferúlico, $p$-cumárico e cafeico $(0-250 \mu \mathrm{M})$ durante $48 \mathrm{~h}$. Como controlo positivo foi usada uma solução de $\mathrm{H}_{2} \mathrm{O}_{2}$ $(1 \mathrm{mM})$, enquanto o DMSO $(0.5 \%$, v/v) foi usado como veículo. Após este período, o ensaio de redução de MTT foi realizado de acordo com protocolos descritos previamente $(28,29)$. Os valores de absorvância para as células tratadas com o veículo (controlo) correspondem a $100 \%$ da viabilidade celular. Para este ensaio, foram 


\section{Crystal violet (CV) staining assay}

The CV staining assay was carried out as a confirmatory assay to evaluate the impact of phenolic compounds on cell viability. First, 786-O cells were cultured at a density of $3 \times 10^{3}$ per well, in 96-well plates, and incubated for $24 \mathrm{~h}$. Then, cells were treated with ferulic, $p$-coumaric or caffeic acids $(0-1000 \mu \mathrm{M})$ for $48 \mathrm{~h}$. A solution of $\mathrm{H}_{2} \mathrm{O}_{2}(1 \mathrm{mM})$ was used as a positive control while $0.5 \%(\mathrm{v} / \mathrm{v})$ of DMSO was used as vehicle control. The CV staining assay was then performed according to previously published protocols $(12,29-31)$. Absorbance values for the vehicle-treated control cells correspond to $100 \%$ of cell viability. For this assay, at least two independent experiments were carried out and six replicates were used for each condition in each independent experiment. The half-maximal inhibitory concentration $\left(\mathrm{IC}_{50}\right)$ was calculated using GraphPad Prism $7^{\circledR}$ statistical software (San Diego, CA, USA).

\section{Results and Discussion}

In previous studies, ferulic, caffeic, and $p$-coumaric acids have shown biological activity towards different tumor cell lines, indicating that these compounds could be promising anticancer agents. Nonetheless, there are also studies in which this class of bioactive compounds did not exhibit anticancer properties.

To the best of our knowledge, there are no previous studies that evaluate the influence of these compounds on cell viability using renal cancer cell models. Hence, in this work, the cytotoxicity of ferulic, caffeic, and $p$-coumaric acids was evaluated in 786-O cells through two different methodologies, the MTT reduction assay and the $\mathrm{CV}$ staining assay.

The MTT reduction assay is one of the most common assays used to evaluate the cytotoxicity of potential anticancer compounds. This assay is based on the assumption that the mitochondrial activity of the most viable cells is constant and the reduction of MTT tetrazolium salt into formazan occurs in the mitochondria of living cells. Thus, an increase or decrease in the number of viable cells depend linearly on their mitochondrial activity $(33,34)$. In this study, the MTT reduction assay results revealed that the efetuadas pelo menos duas experiências independentes e usados pelo menos seis replicados para cada condição em cada uma das experiências independentes.

\section{Ensaio colorimétrico do cristal violeta $(\mathrm{CV})$}

O ensaio colorimétrico do CV foi utilizado como ensaio confirmatório para avaliar o impacto dos compostos fenólicos na viabilidade celular.Inicialmente, as células 786-O foram cultivadas a uma densidade de $3 \times 103$ células por poço, em placas de 96 poços e incubadas durante $24 \mathrm{~h}$. Em seguida, as células foram tratadas com os ácidos ferúlico, $p$-cumárico e cafeico $(0-1000$ $\mu \mathrm{M})$ durante $48 \mathrm{~h}$. Uma solução de $\mathrm{H}_{2} \mathrm{O}_{2}(1 \mathrm{mM})$ foi usada como controlo positivo, enquanto o DMSO (0.5 $\%, \mathrm{v} / \mathrm{v}$ ) foi usado como veículo. Em seguida, o ensaio colorimétrico do $\mathrm{CV}$ foi realizado de acordo com protocolos publicados anteriormente (12,29-31). Os valores de absorvância para as células tratadas com o veículo (controlo) correspondem a 100\% da viabilidade celular. Para este ensaio, foram efetuadas pelo menos duas experiências independentes e usados seis replicados para cada condição em cada uma das experiências independentes. A metade da concentração máxima inibitória $\left(\mathrm{IC}_{50}\right)$ foi calculada utilizando o software estatístico GraphPad Prism $7^{\circledR}$ (San Diego, CA, USA).

\section{Resultados e Discussão}

Estudos anteriores demonstram que os ácidos ferúlico, cafeico e $p$-cumárico apresentam atividade biológica em diferentes linhas celulares, indicando que estes compostos poderão ser promissores agentes antitumorais. No entanto, também existem estudos, nos quais esta classe de compostos bioativos não exibiram propriedades anticancerígenas.

De acordo com o nosso conhecimento, não existem estudos prévios que avaliem a influência destes compostos na viabilidade celular, utilizando modelos celulares de cancro renal. Desta forma, neste trabalho a citotoxicidade dos ácidos ferúlico, cafeico e $p$-cumárico foi avaliada nas células 786-O através de duas metodologias distintas, o ensaio de redução de MTT e o ensaio colorimétrico com $\mathrm{CV}$.

O ensaio de redução de MTT é um dos ensaios mais usados para avaliar a citotoxicidade de potenciais compostos antitumorais. Este ensaio baseia-se no pressuposto de que a atividade mitocondrial das células mais viáveis é constante e que a redução do sal MTT tetrazólio em formazan ocorre nas mitocôndrias das células vivas. Assim, um aumento ou diminuição do número de células viáveis depende linearmente da atividade mitocondrial das mesmas $(33,34)$. Neste 

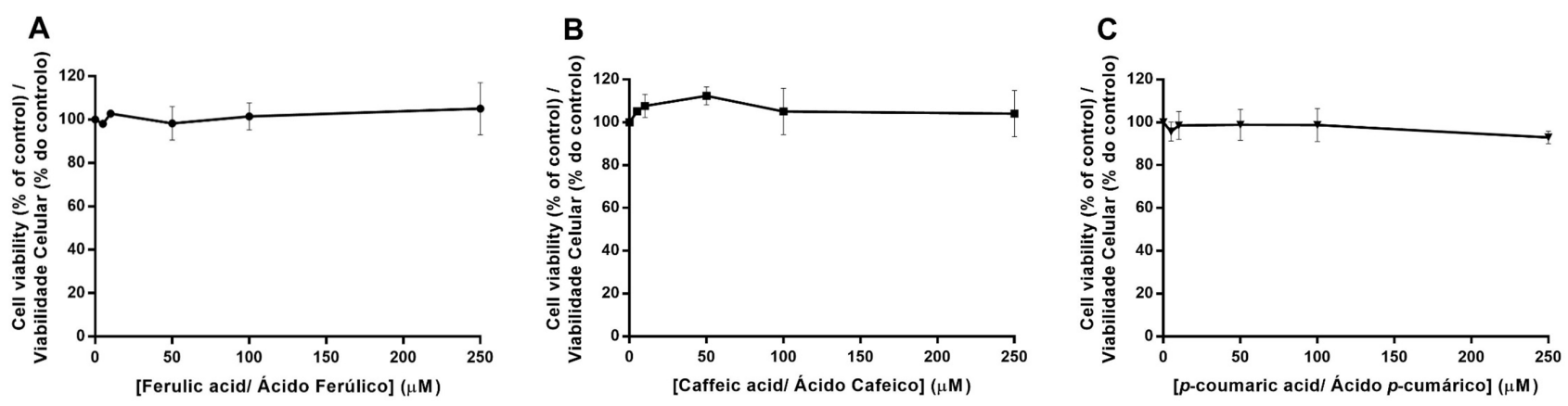

Figure 2 - Cell viability of 786-O cells exposed to ferulic acid (A), caffeic acid (B) and $p$-coumaric acid (C) (0$250 \mu \mathrm{M} ; 48 \mathrm{~h})$. The cell viability was evaluated by the MTT assay. Values represent mean \pm SD $(\mathrm{n}=2-3)$ and are expressed as percentages of the non-treated control cells.

Figura 2 - Viabilidade celular das células 786-O expostas ao ácido ferúlico (A), ácido cafeico (B) e ácido $p$ cumárico (C) (0-250 $\mu \mathrm{M} ; 48$ h). A viabilidade celular foi avaliada pelo ensaio do MTT. Os valores representam a média \pm DP $(n=2-3)$ e estão expressos como percentagens das células controlo não tratadas.

studied compounds $(0-250 \mu \mathrm{M} ; 48 \mathrm{~h})$ did not show cytotoxic effects on this cell line when compared with the non-treated control cells (Figure 2). At the highest studied concentration $(250 \mu \mathrm{M} ; 48 \mathrm{~h})$ of ferulic acid, caffeic acid, and $p$-coumaric acid, the cell viability observed was similar to that of control cells, being $111.1 \%, 104.1 \%$ and $92.9 \%$, respectively. Since MTT reduction assay can be influenced by compounds that modify the cell metabolism and reaction conditions, a confirmatory methodology, the CV staining assay was performed. Moreover, in CV assay, a higher range of concentrations of ferulic, caffeic, and $p$-coumaric acids (up to $1000 \mu \mathrm{M}$ ) was used.

The CV staining assay is a non-enzymatic assay that quantifies the number of adherent cells. This assay is based on the affinity between dye and DNA (34). The amount of dye absorbed depends on the total DNA content in the culture and, consequently, on the number of viable cells. Although the CV staining assay does not provide information about cell functionality, as it is metabolism-independent (34). In this work, after 48 $\mathrm{h}$ treatment, the $\mathrm{CV}$ staining assay revealed that none of the studied compounds showed cytotoxic effects at concentrations up to $250 \mu \mathrm{M}$ (Figure 3), which is in agreement with our previous results obtained with the MTT assay. Nevertheless, a different impact on cell viability was observed when 786-O cells were exposed to higher concentrations (500 and $1000 \mu \mathrm{M})$ of ferulic, caffeic and $p$-coumaric acids (Figure 3 ). The exposure to the higher concentrations of ferulic acid (500 and $1000 \mu \mathrm{M})$ continues to not significantly influence the cell viability of $786-\mathrm{O}$ cells, with these values being $109.5 \%$ and $104.5 \%$, respectively. On the other hand, estudo, os resultados do ensaio de redução de MTT revelaram que os compostos estudados $(0-250 \mu \mathrm{M} ; 48$ h) não demonstraram efeitos citotóxicos nesta linha celular, quando comparados com as células controlo não tratadas (Figura 2). À concentração mais elevada estudada $(250 \mu \mathrm{M} ; 48 \mathrm{~h})$ dos ácidos ferúlico, cafeico e $p$-cumárico, a viabilidade celular foi semelhante à viabilidade celular obtida das células controlo, obtendose $111,1 \%, 104,1 \%$ e $92,9 \%$, respetivamente. Uma vez que o ensaio de redução do MTT pode ser influenciado por compostos que modificam o metabolismo celular e as condições da reação, foi realizada uma metodologia confirmatória, o ensaio colorimétrico do $\mathrm{CV}$. Adicionalmente, no ensaio colorimétrico do $\mathrm{CV}$, foi usado um maior intervalo de concentrações dos ácidos ferúlico, cafeico e $p$-cumárico (até $1000 \mu \mathrm{M}$ ).

$\mathrm{O}$ ensaio colorimétrico do $\mathrm{CV}$ é um ensaio não enzimático que quantifica o número de células aderentes. Este ensaio é baseado na afinidade entre o corante e o ADN (33). A quantidade de corante absorvido depende do conteúdo total de ADN na cultura e, consequentemente, do número de células viáveis. No entanto, o ensaio colorimétrico do $\mathrm{CV}$ não fornece informações sobre a funcionalidade celular, uma vez que é independente do metabolismo (34). Neste estudo, após um tratamento de $48 \mathrm{~h}$, o ensaio colimétrico do $\mathrm{CV}$ revelou que nenhum dos compostos estudados apresentou efeitos citotóxicos às concentrações até $250 \mu \mathrm{M}$ (Figura 3), estando de acordo com os nossos resultados previamente obtidos com o ensaio de redução do MTT. No entanto, observou-se um impacto diferente na viabilidade celular quando as células 786O foram expostas a concentrações mais elevadas (500 e $1000 \mu \mathrm{M})$ dos ácidos ferúlico, cafeico e $p$-cumárico 

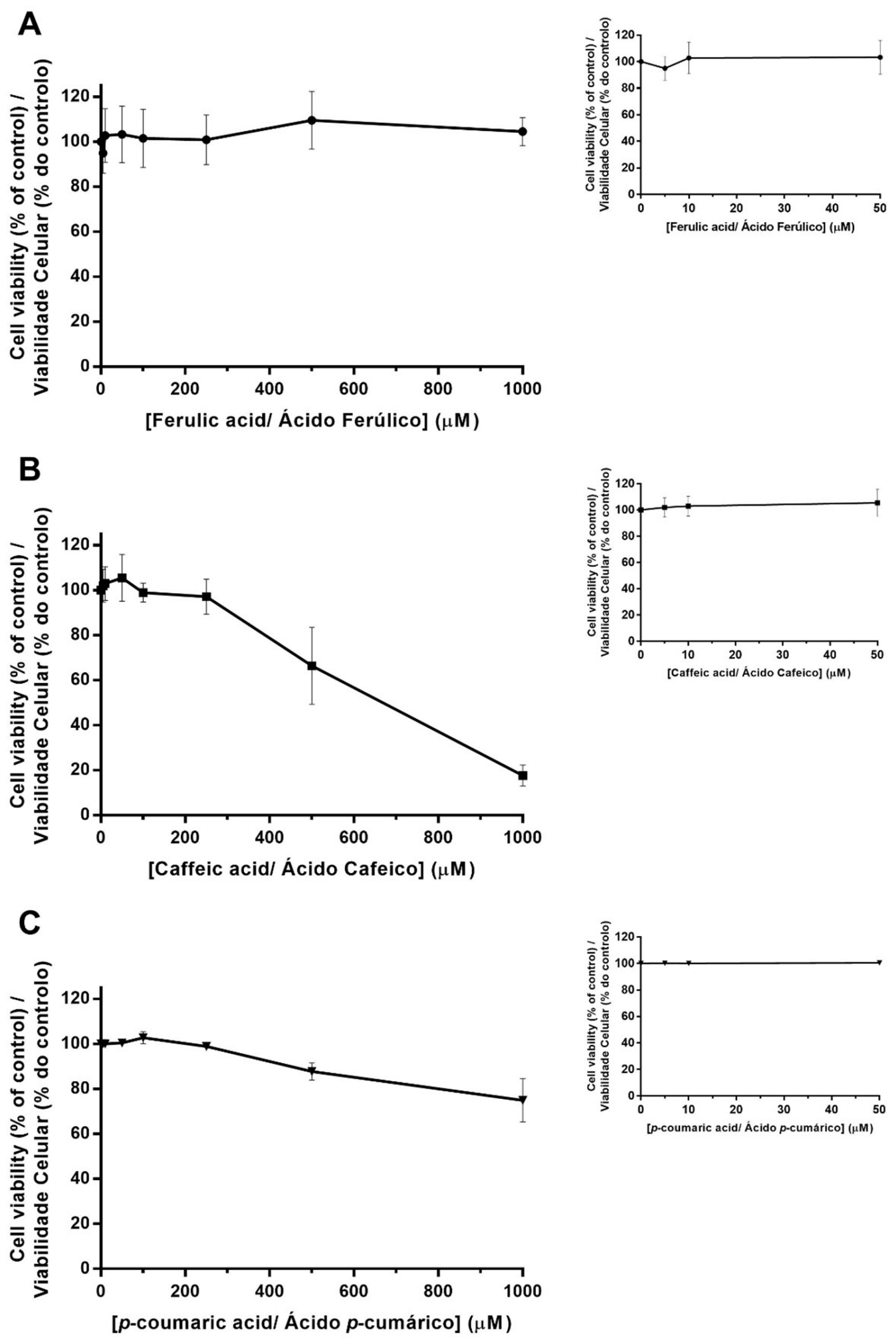

Figure 3 - Cell viability of 786-O cells exposed to ferulic acid (A), caffeic acid (B) and $p$-coumaric acid (C) (0$1000 \mu \mathrm{M} ; 48 \mathrm{~h})$. The cell viability was evaluated by the CV assay. Values represent mean $\pm \mathrm{SD}(\mathrm{n}=2-4)$ and are expressed as percentages of the non-treated control cells. Cell viability of non-treated control cells is shown to the right of each graph.

Figura 3 - Viabilidade celular das células 786-O expostas ao ácido ferúlico (A), ácido cafeico (B) e ácido $p$ cumárico (C) (0-1000 $\mu \mathrm{M} ; 48 \mathrm{~h})$. A viabilidade celular foi avaliada pelo ensaio do CV. Os valores representam a média \pm DP $(n=2-4)$ e são expressos como percentagens das células controlo não tratadas. A viabilidade celular das células controlo não tratadas é monstrada à direita da cada gráfico. 
for $p$-coumaric acid, the results showed cytotoxic effects at the highest concentration evaluated $(1000 \mu \mathrm{M})$, with cell viability of $74.97 \%$. Interestingly, for caffeic acid, a significant decrease in cell viability was observed at the concentration of $500 \mu \mathrm{M}$, when compared with the nontreated control cells, reaching $66.4 \%$ and decreasing to $17.7 \%$ at the concentration of $1000 \mu \mathrm{M}$. The $\mathrm{IC}_{50}$ calculated for the exposure of 786-O cells to caffeic acid (48 h) was $603.4 \mu \mathrm{M}$. Thus, the cell viability results obtained with $\mathrm{CV}$ assay revealed that $786-\mathrm{O}$ cells were more sensitive to caffeic acid, followed by $p$-coumaric acid and then ferulic acid. However, these results obtained for caffeic and $p$-coumaric acids only occur at higher concentrations. Therefore, further studies should be performed using these two bioactive compounds, to understand their safety in non-tumor renal cell lines.

Globally, the results are in accordance with previously published works using other tumor cell lines (Table 1). For instance, in a previous study from our group, performed in another cancer cell line (MDA-MB-231 cells) and using similar experimental conditions $(0-250 \mu \mathrm{M}$; $48 \mathrm{~h}$; CV staining assay), the ferulic acid did not significantly affect the cell viability (15). In another study, using a different renal cancer cell line (769-P), it was observed that ferulic acid $(50 \mu \mathrm{M} ; 48 \mathrm{~h}$; MTT assay) did not significantly suppress cell proliferation (35). Moreover, Serafim et al. (18) also observed that ferulic acid $(0-75 \mu \mathrm{M} ; 24,48$, or $72 \mathrm{~h}$; sulforhodamine B assay) did not inhibit the proliferation of human breast cancer cell lines, including the MDA-MB-231 cells. In another study from our group with U2OS cells (0$1000 \mu \mathrm{M} ; 24 \mathrm{~h}$; CV assay), ferulic acid did not induce a significant decrease in cell viability (36). Furthermore, other reports also revealed that caffeic acid (0-75 $\mu \mathrm{M}$; 24,48 , or $72 \mathrm{~h}$; sulforhodamine B assay) did not exhibit cytotoxic effects on human breast cancer cells (MCF-7, MDA-MB-231, and HS578T) (18). In a previous report with $p$-coumaric acid (0-10 $\mathrm{mM}$; $48 \mathrm{~h}$; MTT assay) at concentrations higher than $750 \mu \mathrm{M}$, cytotoxic effects in colon carcinoma (HT 29) and human colorectal carcinoma (HCT-15) cells were observed (37).

Even though there are certain studies in accordance with our results, there are also some in vitro studies that demonstrated that these compounds not only decrease the cell viability and the cell proliferation but also induce apoptosis in different cancer cell lines (Table 1), using a concentration range similar to ours (38-42). For example, in a previous study, it was reported that ferulic acid, at concentrations up to $100 \mu \mathrm{M}$, decreased breast cancer MDA-MB-231 cell viability (38). Moreo-
(Figura 3). A exposição a concentrações mais elevadas de ácido ferúlico $(500$ e $1000 \mu \mathrm{M})$ continuou a não influenciar significativamente a viabilidade celular das células 786-O, sendo a mesma igual a $109,5 \%$ e $104,5 \%$, respetivamente. Por outro lado, para o ácido $p$-cumárico os resultados revelaram efeitos citotóxicos à concentração mais elevada estudada $(1000 \mu \mathrm{M})$, obtendo-se uma viabilidade celular de 74,97 \%. Curiosamente, para o ácido cafeico foi observada uma diminuição significativa da viabilidade celular à concentração de $500 \mu \mathrm{M}$, em comparação com as células controlo não tratadas, obtendo-se um valor de $66,4 \%$ que diminui para $17,7 \%$ à concentração de 1000 $\mu \mathrm{M}$. O valor de $\mathrm{IC}_{50}$ calculado para a exposição das células 786-O ao ácido cafeico $(48 \mathrm{~h})$ foi de $603.4 \mu \mathrm{M}$. Assim, estes resultados de viabilidade celular obtidos com o ensaio colorimétrico do $\mathrm{CV}$, revelaram que as células 786-O foram mais sensíveis ao ácido cafeico, em seguida ao ácido $p$-cumárico e depois ao ácido ferúlico. No entanto, estes resultados obtidos para os ácidos cafeico e $p$-cumárico só ocorrem às concentrações mais elevadas. Desta forma, mais estudos devem ser efetuados utilizando estes dois compostos bioativos, para compreender a sua segurança em linhas celulares renais não tumorais.

Globalmente, os resultados estão de acordo com outros trabalhos previamente publicados utilizando outras linhas celulares tumorais (Tabela 1). Por exemplo, num estudo previamente realizado pelo nosso grupo, utilizando outra linha celular tumoral (células MDAMB-231) e em condições experimentais semelhantes (0-250 $\mu \mathrm{M} ; 48 \mathrm{~h}$, ensaio colorimétrico do CV), o ácido ferúlico não afetou significativamente a viabilidade celular (12). Num outro estudo, utilizando uma linha celular de cancro renal diferente (769-P), observou-se que o ácido ferúlico ( $50 \mu \mathrm{M} ; 48$ h; ensaio redução do MTT) não suprimiu significativamente a proliferação celular (34). Para além disto, Serafim e colaboradores (16) também observaram que o ácido ferúlico $(0-75 \mu \mathrm{M} ; 24$, 48 ou $72 \mathrm{~h}$; ensaio sulforodamina B) não inibiu a proliferação de linhas celulares humanas de cancro da mama, incluindo as células MDA-MB-231. Num outro estudo previamente realizado pelo nosso grupo com células U2OS (0-1000 $\mu \mathrm{M}$; 24 h; ensaio colorimétrico do CV), o ácido ferúlico não induziu uma diminuição significativa da viabilidade celular (35). Adicionalmente, outros estudos também revelaram que o ácido cafeico (0-75 $\mu \mathrm{M} ; 24,48$ ou $72 \mathrm{~h}$; ensaio sulforodamina $\mathrm{B}$ ) não apresentou efeitos citotóxicos em células humanas de cancro da mama (MCF-7, MDA-MB-231 e HS578T) (18). Num estudo prévio com o ácido $p$-cumárico (0-10 mM; $48 \mathrm{~h}$; ensaio de redução do MTT)a concentrações superiores a $750 \mu \mathrm{M}$, não foram observados efeitos citotóxi- 


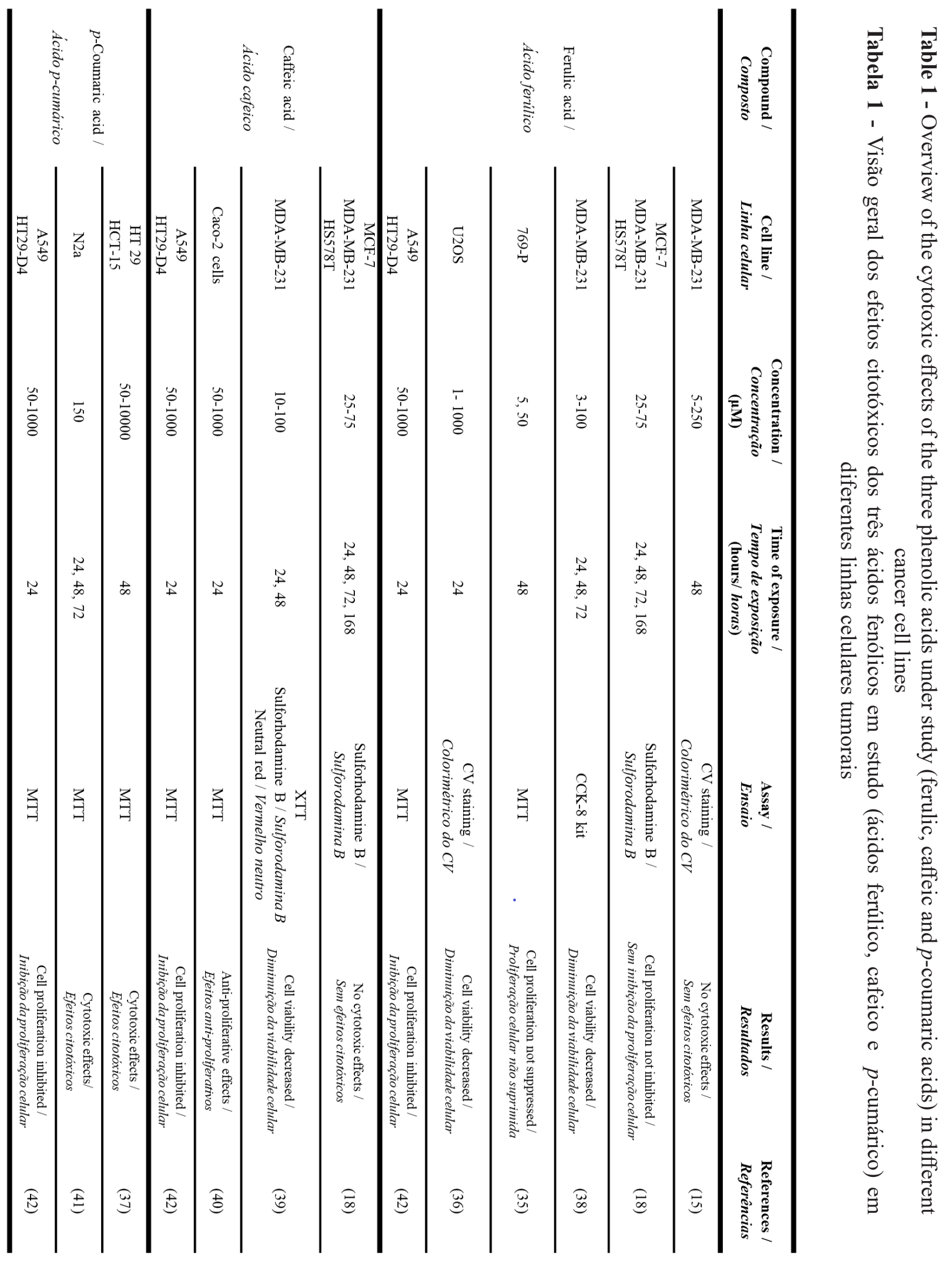


ver, in another study, using the same cell line and the XTT, sulforhodamine B, and neutral red assays, after a 24 or $48 \mathrm{~h}$ period of exposure to caffeic acid (10-100 $\mu \mathrm{M})$, the cell viability decreased in a concentration-dependent manner (39). In another study, using the MTT assay, it was also observed that caffeic acid (50-1000 $\mu \mathrm{M}, 24 \mathrm{~h}$ ) led to an anti-proliferative effect in Caco-2 cells (40). Moreover, another research study revealed that $p$-coumaric acid $(150 \mu \mathrm{M})$ decreased the cell viability of neuroblastoma cells, being this decrease more significant after $72 \mathrm{~h}$ of treatment (41). Furthermore, Bouzaiene et al. (2015), also observed that the exposure to ferulic, caffeic and $p$-coumaric acids $(50-1000 \mu \mathrm{M}$, $24 \mathrm{~h}$, MTT assay) significant inhibited, in a concentration-dependent manner, the proliferation of human lung (A549) and colon (HT29-D4) cancer cells (42). These discrepancies between studies can be related to different experimental conditions used as well as to some inherent cellular mechanisms of each cell type. These studies prove the importance of using different methodologies, experimental conditions, and models when evaluating the possible applicability of phenolic acids as anticancer agents.

\section{Conclusion}

In this study, we investigated the cytotoxicity of ferulic, caffeic, and $p$-coumaric acids in a human renal cancer cell line. Our results revealed that up to $250 \mu \mathrm{M}$, none of the studied natural compounds showed cytotoxic effects on the 786-O cell line under our experimental conditions. Nonetheless, at higher concentrations, in the presence of caffeic and $p$-coumaric acids, cytotoxic effects were observed. Therefore, more studies using these two natural compounds should be conducted to understand their safety in non-tumor cells. Further studies with other methodologies, experimental parameters, or using other cancer cell lines should also be considered. Additionally, this work also highlights the importance of publishing negative results, since this data may be fundamental to redirect further studies. cos em células de carcinoma do cólon (HT 29) e em células de carcinoma colorretal humano (HCT-15) (37). Contudo, embora existam alguns estudos concordantes com os nossos resultados, existem também alguns estudos in vitro que demonstraram que estes compostos diminuem não só a viabilidade e a proliferação celular bem como induzem a apoptose em várias linhas celulares tumorais (Tabela 1), utilizando um intervalo de concentrações semelhante ao do nosso trabalho experimental (38-42). Por exemplo, num estudo prévio, foi reportado que o ácido ferúlico, a concentrações até 100 $\mu \mathrm{M}$, diminuiu a viabilidade das células MDA-MB-231 de cancro da mama (38). Adicionalmente, num outro estudo, usando a mesma linha celular e utilizando os ensaios do XTT, sulforodamina B e vermelho neutro, após um período de exposição de 24 ou 48 h ao ácido cafeico (10-100 $\mu \mathrm{M})$, a viabilidade celular obtida diminuiu de forma dependente da concentração (39). Num outro estudo, utilizando o ensaio de redução do MTT, também foi observado que, o ácido cafeico (50-1000 $\mu \mathrm{M} ; 24$ h) causou efeitos antiproliferativos em células Caco-2 (40). Para além disto, outro trabalho revelou que o ácido $p$-cumárico $(150 \mu \mathrm{M})$, diminuiu a viabilidade celular de células do neuroblastoma, sendo a diminuição mais significativa após $72 \mathrm{~h}$ de tratamento (41). Para além disto, Bouzaiene et al. (2015), também observaram que a exposição aos ácidos ferúlico, cafeico e $p$-cumárico (50-1000 $\mu \mathrm{M}, 24$ h, ensaio de redução do MTT) inibiu, de forma significativa e dependente da concentração, a proliferação de células tumorais do pulmão humano (A549) do cólon (HT29-D4) (42). Estas discrepâncias entre os diversos estudos podem estar relacionadas com as diferentes condições experimentais utilizadas, assim como com a diferença dos mecanismos celulares característicos de cada tipo de células. Estes estudos demonstram a importância de usar diferentes metodologias, modelos e condições experimentais, quando se pretende avaliar a possível aplicabilidade dos ácidos fenólicos como agentes antitumorais.

\section{Conclusão}

Neste estudo foi investigado a citotoxicidade dos ácidos ferúlico, cafeico e $p$-cumárico em linhas celulares renais tumorais humanas. Os nossos resultados revelaram que até $250 \mu \mathrm{M}$, nenhum dos compostos naturais estudados mostrou efeitos citotóxicos na linha celular 786$\mathrm{O}$, sob as nossas condições experimentais. Contudo, às concentrações mais elevadas, foram observados efeitos citotóxicos na presença dos ácidos cafeico e $p$-cumárico. Desta forma, mais estudos usando estes 


\section{Acknowledgments}

This work was financially supported by Fundação para a Ciência e Tecnologia (FCT, Portugal), through funding UID/DTP/04567/2019. Rita Caparica and Ana Júlio would like to acknowledge ALIES for the grant PADDIC 2018-2019.

\section{Conflict of Interests}

The senior editor co-authoring this manuscript had no participation in the review nor in the decision process.

All authors have declared there were no financial and/ or personal relationships that may present a potential conflict of interest. dois compostos naturais devem ser realizados com o intuito de se perceber a sua segurança em células nãotumorais. Novos estudos com outras metodologias, parâmetros experimentais ou utilizando diferentes linhas celulares devem ser realizados. Adicionalmente, este estudo permitiu ainda salientar a importância de publicar resultados negativos, uma vez que estes resultados poderão contribuir para redirecionar estudos futuros.

\section{Agradecimentos}

Este trabalho foi financiado através da Fundação para a Ciência e Tecnologia (FCT, Portugal), no âmbito do projeto UID/DTP/04567/2019. Rita Caparica e Ana Júlio gostariam ainda de agradecer à ALIES pela bolsa PADDIC 2018-2019.

\section{Conflito de Interesses}

O editor senior envolvido na autoria deste manuscrito não teve qualquer participação no processo de revisão ou de decisão.

Todos os autores declararam não haver relações financeiras e/ou pessoais que possam representar um potencial conflito de interesses. 


\section{References / Referências}

1. Mathur S, Hoskins C. Drug development : Lessons from nature ( Review ). Biomed Reports. 2017;6(6):612-4

2. Taofi O, González-Paramás AM, Barreiro MF, Ferreira ICFR. Hydroxycinnamic Acids and Their Derivatives : Future Perspectives , a Review. molecules. 2017;22(2):1-24.

3. Tungmunnithum D, Thongboonyou A, Pholboon A. Flavonoids and Other Phenolic Compounds from Medicinal Plants for Pharmaceutical and Medical Aspects : An Overview. medicines. 2018;5(3):1-16.

4. Huang W, Cai Y, Zhang Y, Huang W, Cai Y. Natural Phenolic Compounds From Medicinal Herbs and Dietary Plants : Potential Use for Cancer Prevention. Nutr Cancer. 2010;62(1):1-20.

5. Heleno SA, Martins A, Queiroz MJRP, Ferreira ICFR. Bioactivity of phenolic acids: Metabolites versus parent compounds: A review [Internet]. Vol. 173, Food Chemistry. 2015 [cited 2018 Sep 14]. p. 501-13. Available from: http://linkinghub.elsevier.com/retrieve/pii/S0308814614016197

6. Vuolo MM, Lima VS, Roberto M, Junior M. Phenolic Compounds: Structure, Classification, and Antioxidant Power [Internet]. Bioactive Compounds. Elsevier Inc.; 2019. 33-50 p. Available from: https://doi.org/10.1016/B978-0-12-814774-0.00002-5

7. Rosa LA de la, Moreno-escamilla JO, Rodrigo-garcía J, Alvarez-parrilla E. Phenolic Compounds [Internet]. Postharvest Physiology and Biochemistry of Fruits and Vegetables. Elsevier Inc.; 2019. 253-272 p. Available from: http://dx.doi.org/10.1016/B978-0-12-813278-4.00012-9

8. Dias MI, Sousa MJ, Alves RC, Ferreira ICF. Exploring plant tissue culture to improve the production of phenolic compounds : A review. Ind Crop Prod [Internet]. 2016;82:922. Available from: http://dx.doi.org/10.1016/j.indcrop.2015.12.016

9. Caparica R, Júlio A, Araújo MEM, Baby AR, Fonte P, Costa JG, et al. Anticancer Activity of Rutin and Its Combination with Ionic Liquids on Renal Cells. Biomolecules. 2020;10(2):1-15

10. Xu D, Hu M, Wang Y, Cui Y. Antioxidant Activities of Quercetin and Its Complexes for Medicinal Application. Molecules. 2019;24(6):1-15.

11. Duan J, Yue W, E JY, Malhotra J, Lu S, Gu J, et al. In vitro comparative studies of resveratrol and triacetylresveratrol on cell proliferation , apoptosis , and STAT3 and NF $\kappa$ B signaling in pancreatic cancer cells. Nat Publ Gr [Internet]. 2016;(August):1-10. Available from: http://dx.doi.org/10.1038/srep31672

12. Salehi B, Mishra AP, Nigam M, Sener B, Kilic M. Resveratrol : A Double-Edged Sword in Health Benefits. Biomedicines. 2018;6(3):1-20.

13. Kumar A, Manjula M. Anticarcinogenic action of quercetin by downregulation of phosphatidylinositol 3-kinase (PI3K) and protein kinase C (PKC) via induction of p53 in hepatocellular carcinoma (HepG2) cell line. Mol Biol Rep. 2015;42(9):1407-17.

14. Jara P, Spies J, Cárcamo C, Arancibia Y, Vargas G, Martin C, et al. The Effect of Resveratrol on Cell Viability in the Burkitt's Lymphoma Cell Line Ramos. Molecules. 2017;23(1):1-12

15. Caparica R, Júlio A, Baby AR, Araújo MEM, Fernandes AS, Costa JG, et al. Choline-Amino Acid Ionic Liquids as Green Functional Excipients to Enhance Drug Solubility. Pharmaceutics [Internet]. 2018;10(4):1-13. Available from: https://doi.org/10.3390/pharmaceutics10040288

16. Rio D Del, Rodriguez-mateos A, Spencer JPE, Tognolini M, Borges G, Crozier A. Dietary (Poly)phenolics in Human Health: Structures, Bioavailability, and Evidence of Protective Effects Against Chronic Diseases 1. Antioxid Redox Signal. 2013;18(14).

17. Magnani C, Isaac V, Salgado H. Caffeic acid: A review of its potential use in medications and cosmetics. Anal Methods. 2014;(10):3203-10.

18. Serafim TL, Carvalho FS, Marques MPM, Calheiros R, Silva T, Garrido J, et al. Lipophilic Caffeic and Ferulic Acid Derivatives Presenting Cytotoxicity against Human Breast Cancer Cells. Chem Res Toxicol. 2011;763-74.

19. Mancuso C, Santangelo R. Ferulic acid: Pharmacological and toxicological aspects. FOOD Chem Toxicol [Internet]. 2014;65:185-95. Available from: http://dx.doi. org/10.1016/j.fct.2013.12.024

20. Kumar N, Pruthi V. Potential applications of ferulic acid from natural sources. Biotechnol Reports [Internet]. 2014;4:86-93. Available from: http://dx.doi.org/10.1016/j. btre.2014.09.002

21. Pei K, Ou J, Huang J, Ou S. p -Coumaric acid and its conjugates : dietary sources, pharmacokinetic properties and biological activities. Sci Food Agric. 2016;

22. Joshua S, Vachana P, Prince E, Mahaboobkhan S. Ameliorative effect of p -coumaric acid, a common dietary phenol, on adjuvant-induced arthritis in rats. Rheumatol Int. 2013;325-34.

23. Yeh I-J, Chen S-C, Yen M-C, Wu Y-H, Hung C-H, Kuo P-L. 6-Shogaol Suppresses 2-Amino-1-Methyl-6- Phenylimidazo [4,5-b] Pyridine (PhIP)-Induced Human 786-O Renal Cell Carcinoma Osteoclastogenic Activity and Metastatic Potential. Nutrients. 2019;11(10):1-14.

24. Ou Y, Li J, Wang J, Chang C, Wu C, Chen W, et al. Fibronectin Promotes Cell Growth and Migration in Human Renal Cell Carcinoma Cells. Mol Sci. 2019;20(11):1-16.

25. Shao Y, Liu Z, Liu J, Wang H, Huang L, Lin T, et al. Expression and epigenetic regulatory mechanism of BNIP3 in clear cell renal cell carcinoma. Int J Oncol. 2019;54:348-60.

26. Lin CY, Chen P-N, Hsu L-S, Kuo DYK, Chu S-C, Hsieh Y-SH. Inhibition of the invasion and migration of renal carcinoma 786-o-si3 cells in vitro and in vivo by Koelreuteria formosana extract. Mol Med Rep. 2014;3334-42.

27. Escudier B, Porta C, Schmidinger M, Bex A, Khoo V, Gruenvald V, et al. Renal cell carcinoma : ESMO Clinical Practice Guidelines for diagnosis, treatment and follow-up. Ann Oncol. 2016;27(August).

28. Júlio A, Caparica R, Lima SAC, Fernandes AS, Rosado C, Prazeres DMF, et al. Ionic Liquid-Polymer Nanoparticle Hybrid Systems as New Tools to Deliver Poorly Soluble Drugs. nanomaterials. 2019;9(8):1-17.

29. Santos de Almeida T, Júlio A, Saraiva N, Fernandes AS, Araújo MEM, Baby AR, et al. Choline- versus imidazole-based ionic liquids as functional ingredients in topical delivery systems: cytotoxicity, solubility, and skin permeation studies. Drug Dev Ind Pharm. 2017;43(11):1858-65.

30. Costa JG, Saraiva N, Guerreiro PS, Louro H, Silva MJ, Miranda JP, et al. Ochratoxin A-induced cytotoxicity, genotoxicity and reactive oxygen species in kidney cells: an integrative approach of complementary endpoints. Food Chem Toxicol [Internet]. 2015; Available from: http://dx.doi.org/10.1016/j.fct.2015.11.018

31. Costa JG, Saraiva N, Batinic-Haberle I, Castro M, Oliveira NG, Fernandes AS. The SOD Mimic MnTnHex-2-PyP $5+$ Reduces the Viability and Migration of 786-O Human Renal Cancer Cells. antioxidants. 2019;8(10):1-14.

32. Fernandes AS, Serejo J, Gaspar J, Cabral F, Bettencourt AF, Rueff J, et al. Oxidative injury in V79 Chinese hamster cells: Protective role of the superoxide dismutase mimetic MnTM-4-PyP. Cell Biol Toxicol. 2010;26(2):91-101.

33. Meerloo J Van, Kaspers GJL, Cloos J. Cell Sensitivity Assays: The MTT Assay. In: Cancer Cell Culture: Methods and Protocols [Internet]. second. Springer Science+Business Media; 2011. p. 237-45. Available from: http://link.springer.com/10.1007/978-1-61779-080-5

34. Śliwka L, Wiktorska K, Suchocki P, Milczarek M, Mielczarek S, Lubelska K, et al. The comparison of MTT and CVS assays for the assessment of anticancer agent interactions. PLoS One. 2016;11(5):1-17.

35. Konduri SD, Bangaru MLY, Do PT, Chen S, Woodliff J, Kansra S. In Vitro Growth Suppression of Renal Carcinoma Cells by Curcumin. J Patient-Centered Res Rev. 2015;2(4):156-64.

36. Nicolai M, Almeida N, Rijo P, Costa JG, Saraiva N, Fernandes AS. Cytotoxic effect of antioxidants found in food from plant origin on human osteosarcoma U2OS Cells Biomed Biopharm Res. 2019;1(16):89-96.

37. Jaganathan SK, Supriyanto E, Mandal M. Events associated with apoptotic effect of $p$-Coumaric acid in HCT-15 colon cancer cells. World J Gastroenterol. 2013;19(43).

38. Zhang X, Jiang R, Li H. Ferulic acid exerts antitumor activity and inhibits metastasis in breast cancer cells by regulating epithelial to mesenchymal transition. Oncol Rep. 2016;271-8.

39. Kabała-Dzik A, Rzepecka-Stojko A, Kubina R, Jastrzebska-Stojko Z, Stojko R, Wojtyczka RD, et al. Migration Rate Inhibition of Breast Cancer Cells Treated by Caffeic Acid and Caffeic Acid Phenethyl. Nutrients. 2017;9(10):1-19.

40. Ekbatan SS, Li XQ, Ghorbani M, Azadi B, Kubow S. Chlorogenic acid and its microbial metabolites exert anti-proliferative effects, S-phase cell-cycle arrest and apoptosis in human colon cancer caco-2 cells. Int J Mol Sci. 2018;19(3):1-13.

41. Shailasree S, Venkataramana M, Niranjana SR, Prakash HS. Cytotoxic Effect of p -Coumaric Acid on Neuroblastoma, N2a Cell via Generation of Reactive Oxygen Species Leading to Dysfunction of Mitochondria Inducing Apoptosis and Autophagy. Mol Neurobiol. 2014;1-12.

42. Bouzaiene NN, Kilani Jaziri S, Kovacic H, Chekir-Ghedira L, Ghedira K, Luis J. The effects of caffeic, coumaric and ferulic acids on proliferation, superoxide production, adhesion and migration of human tumor cells in vitro. Eur J Pharmacol [Internet]. 2015;766:99-105. Available from: http://dx.doi.org/10.1016/j.ejphar.2015.09.044 